\title{
Nigeria's Ambition For the United Nations Security Council Within the Context of Historical Antecedents and Domestic Realities: Analysis of the Prospects and Challenges
}

\author{
Aderemi Opeyemi Ade-Ibijola \\ Department of Politics, University of KwaZulu Natal, \\ Pietermaritzburg, South Africa
}

\begin{abstract}
This paper draws a linkage between Nigeria's roles during the struggle against colonialism in Africa and the country's quest for a permanent seat on the United Nations Security Council (UNSC). The paper argues that Nigeria's past roles in African decolonization process especially its efforts toward the eradication of aparthied and colonialism in Southern Africa and its current domestic condition have both positive and negative implications for the country's ambition. The paper submits that Nigeria's greatest credentials for the UNSC seat lie not in its records of service to the African cause but in the combination of that record with an appreciable domestic condition which is epitomized by good governance, protection of human rights, sound and enduring democratic institutions, dedicated political leadership, zero tolerance for corruption and functional judiciary in the current context. Nigeria's success also depends on ensuring security on the home front, tackling mass impoverishment and working towards a robust economy.
\end{abstract}

Key words: African Union, United Nations, Good Governance, United Nations Security Council, Nigeria, Domestic Condition

\section{INTRODUCTION}

Assessing Nigeria's ambition for the UN Security Council within the context of the country's antecedents in the decolonization struggle in Africa is of utmost importance. There is a linkage in the contemporary sense between Nigeria's leadership roles in the decolonization of Africa and the country's desire to become one of Africa's permanent representatives on the SC should the seat become available as anticipated. If the roles played by Nigeria during the course of the 20th century in the decolonization of Africa are truly a function of its leadership abilities as the Nigerian past and present leaders, diplomats and even authors have argued, the question then becomes: have these leadership abilities which Nigeria projects in order to secure regional, continental and global supports impacted positively on the socio-political and economic life of the country?

Have Nigerian leaders who continue to seek a permanent seat for the country on the SC been able to replicate the leadership virtues they are projecting to the world on the domestic front? On the other hand, what are the implications of Nigeria's roles in African decolonization for its contemporary quest to get a permanent seat for itself on an enlarged UNSC? Do these roles suggest Nigeria will be truly representative of Africa and Africans interests on the SC going by its antecedents? In the search for a UNSC permanent seat Nigeria has been moved by the conviction that "no single African nation has done as much as Nigeria for Africa and the Africans." Advocates of a UNSC seat for Nigeria also believe that "Nigeria has more than paid its dues to Africa and Africans." These facts constitute the positive implications for Nigeria in 
its quest for glory in global politics. In view of the above, the paper examines the prospects and challenges which Nigeria faces in respect to the issues enumerated above.

\section{On Nigeria's Rich Antecedents and Contemporary Political Ambition: The Prospects}

There are contemporary implications of Nigeria's roles in African decolonization issues for the country's quest for a permanent membership seat on the UNSC. In light of this, the present subsection discusses the challenges and prospects for the country's political ambition. Suffice it to say that Nigeria's bid for the UNSC has drawn part of its strength from its unmatchable records at least by any African country in the struggle against colonialism and racism in Africa. If there is a major factor that puts Nigeria ahead of other African leading contenders for the UNSC seat, it will definitely be its undeniable accomplishments in the service to the Black component of humanity. The country played an outstanding leadership role on the colonial issues over a period of 30 years in the United Nations which justified its claim to continental leadership.

The consistencies of Nigeria's articulations of the colonial situation in Africa on the platform of the world body and the sacrifices which went with it will have positive implications for the country's ambition regarding global politics should the AU decide to ask contenders to present their scorecards in the service to Africa. It is simply a case of asking each aspiring African country for the permanent SC seat what they have done for Africa. After the attainment of political independence from Britain in 1960, Nigeria, motivated by the desire to play a dominant leadership role in African affairs swung into action to assert and to establish itself as Africa's most influential country throughout the colonial period.

As early as January 1960, ten months prior to its independence, Prime Minister Abubakar Tafawa Balewa had told the national parliament that the country would have a "wonderful opportunity to speak for Africa at the United Nations." The role Nigeria played during the struggle against colonialism in Africa is indicative of the roles it will play if selected as one of Africa's representatives on an enlarged UNSC. Its assertiveness, boldness, unintimidating presence and the ability to stand up against external forces when the issue at stake revolves around the destiny and interests of black people is second to none in the annals of African history. There is supportive evidence to this claim and the sacrifices that went with Nigeria's roles during the struggle against the forces of colonialism on the continent. For instance, Joseph Garba, Nigeria's Foreign Affairs Minister (1975-1979) and the President of the UN General Assembly (1989-1990) once said: "Nigeria ... made enemies of erstwhile friends - all on account of their attitude towards the South Africa question. We have formulated economic policies that have sometimes been detrimental to our own development because of our commitment to the eradication of apartheid."

The former Nigerian Minister Joe - Garba was also quoted to have authoritatively stated that "Nigeria had lost an estimated \$45billion over 15 years for refusing to export oil to South Africa." This was part of the measures taken to put pressure on the apartheid regime to abolish its racial policies. The forgoing therefore attests to Nigeria's competence and political will to defend the interests of fellow Africans with unwavering commitment and unyielding tenacity when the occasion calls for it. This was the case during the decades - long struggle against colonial subjugation. Thus, for Africa to have a robust representation on the UNSC, the AU member states should insist on having one of their own that has a track record of service to the African continent.

Due to Nigeria's hard stance against apartheid, the P.W. Botha's apartheid Presidency (19841989) attempted to destablize Nigeria militarily when he wooed Equatorial Guinea to provide 
South Africa with a strategic military location where it could launch attacks into the Nigerian territory. Nigeria's government responded to this threat to its national security promptly without pulling out of the struggle against apartheid as Botha and his comrades would have loved. The Nigerian government exerted pressures on the government of Equatorial Guinea to severe the cozy relationship with South Africa. The pressure was sustained until it yielded the desired result that forced President Obiang Mbasogo to expel the South Africans from his country. With the apartheid military presence in Equatorial Guinea dismantled, the Nigerian Head of State General Ibrahim Babangida paid a two-day official visit to the Equatorial Guinea in June 1988 to signal the restoration of cordial bilateral relations between the two countries (Fawole 2003:166).

Nigeria under the Babangida regime (1985-19930 also gave financial assistance to the frontline states in Southern Africa to help them repair the damage inflicted on them by the South African apartheid security forces which invaded their territories in search of freedom fights and ANC sympathizers. The foregoing clearly shows that Nigeria has never shied away from defending and upholding the interests of fellow Africans even in the face of adversity. Thus, going by experience and its records, no other country in Africa is deserving of that seat than Nigeria. The mechanisms that the AU will leverage on to elect/select its representatives for the available two slots for Africa on the SC must consider this leadership virtue in the choice of candidates that will represent Africa. To restore the dignity of the black man, Nigeria left no stone unturned. According to Akinjide Osuntokun, Nigeria "... sacrificed the good will of the West and economic development in order to see to the total liberation of Africa." The nationalization of the British Petroleum, the Barclays Bank and other British economic interests in Nigeria in the late 1970s shocked not only Britain - Nigeria's former colonial power but also a large population of Nigerians who considered it unthinkable that Nigeria would move against Britain with such venom just because Margret Thatcher led British government of the time delayed in granting independence to Rhodesia (Now Zimbabwe).

In the case of South Africa, Nigeria applied measures that were aimed at putting pressure on the apartheid regime of Pretoria to change its racial policies. As Bola Akinterinwa noted,

Nigeria under General Obasanjo as Head of State, directed all Nigerian diplomatic missions abroad not to issue to any holder of South African passport in which there was a South African visa. In the strategic calculations of the Nigerian government, any visitor or traveler to South Africa could not but have interests that were likely to be inimical to those of Nigeria in South Africa. Consequently, the friends of South Africa were not wanted in Nigeria.

As earlier argued, it will be of immense benefit for African states if their choice of representatives on an enlarged SC is assessed against this background. If this is done, the above holds a positive implication for Nigeria's candidacy with regard to the SC seat. Another positive implication of Nigeria's role in African decolonization for its UNSC seat ambition lie in the promotion of articles 1-5 of the UN Charter on Human Rights which states that human beings are born free and equal in dignity and rights, entitled to all rights and freedom, shall not be held in slavery or servitude, and above all shall not be subjected to torture or cruel, inhuman or degrading treatment or punishment. The Articles also forbid discrimination of human beings on the basis of their colour, nationality, creed, origin, sex, etc. Nigeria played a key role in the promotion of these principles as enshrined in the UN Articles during the struggle against colonialism and racism in Africa. This commitment was captured in the inaugural address of President Shehu Shagari in 1979 thus: 
... Also it is our national will that Africa shall be free, free of racial bigotry, free of oppression, and free from the vestiges of colonialism. My government is determined to see the cause of justice and human decency prevail in Namibia, Zimbabwe, and South Africa. We shall continue to support all forces of progress and oppose all forces of oppression in Africa and elsewhere. I hereby reaffirm our faith and support for the Charter of the United Nations and the Universal Declaration of Human Rights. . .

In respect of the above, Nigeria has done creditably well to help promote and uphold one of the basic principles upon which the UN system is founded as pledged by Nigerian Prime Minister Balewa upon the country's admission into the organization in October 1960 that: "We are committed to uphold the principles upon which the United Nations Organization is founded." Conclusively, the section has given dissusssed the prospects of Nigeia's case for the UNSC seat vis-à-vis its past records of service to Africa during the struggle against colonailsim in Africa. It has established a linkage between the country's role in African decolonization issues in the UN and the contemporary desire to represent African in a permanent capacity on the UNSC. The above discursion demonstrate Nigeria's capacity and strength of character over a period of 30 years in the struggle against colonialism on the continent and reckoned that if given the opportunity to serve Africa, the country has the potentials to advance, and protect the interest of Africa on the global stage. The next section addresses the issues that may cost the country this opportunity.

\section{THE CHALLENGES}

The preceding section examined the positive implications of Nigeria's role in African decolonization issues in the UN for the country's contemporary political ambition with regard to the UNSC. Here, we shall examine the factors that threaten Nigeria's ambitions. In considering these issues, there is a need to understand what the phrase "Domestic Condition" stands for before beginning with the discussion. This phrase was used by Ambassador Olu Sanu to explain the dilemma of the Nigerian State in the race for UNSC seat. The domestic condition according to the Nigerian diplomat refers to the socio-political and economic realities on the home front which does not portray the country as a serious contender for the UNSC seat.

These realities dictate that Nigeria must first of all put its house in order and concentrate inwardly to develop the country. He submitted that the country's leadership and its foreign policy machinery should not ignore this factor which will weigh heavily in the minds of members of the UN when the additional seat for Africa comes under consideration. Ambassador Sanu recalled that it was this factor that robbed Chief S.O. Adebo of the UN Secretary General position despite being seen as the most qualified candidate for the job. These factors will be considered under this section in order to establish the fact that Nigeria's greatest credentials lie not in its records of service to the African cause but in the combination of that record with appreciable domestic condition. What then are these prevailing domestic conditions? The following offers answers to this question.

Corruption Pandemic - If there is any factor that will stand in Nigeria's way to becoming a permanent member of the UNSC, it is corruption. Corruption is the greatest evil that has bedeviled Nigeria since independence. It was corruption which birthed all the socio- political and economic problems that have faced Nigeria for the better part of it post-colonial life. That Nigeria is where it is today in terms of development is largely due to absence of financial probity, accountability, moral uprightness and sacrificial political leadership in the country's. 
As a result, the country has repeatedly failed to demonstrate moral leadership due to lack of political will. Corruption has become the most talked about topic about Nigeria in recent times. According to Ire Omo - Bare: "No discussion of Nigeria can be complete without, at least, a brief mention of the problem of corruption." This underscores the pandemic nature of the problem which has become worrisome to many patriotic citizens of the country who have ceaselessly lamented the country's degeneration into this infamy. Pat Utomi, A Professor of Political Economy and Management Expert, described the Nigerian system as "an extremely corrupt system". He noted regrettably that this has impeded the country's growth in every aspect of its national life.

The corruption pandemic in Nigeria has a devastating effect on the country. According to former Vice President of the World Bank and a two-time Nigerian Minister, ObiageliEzekwesili, corruption was largely responsible for Nigeria's stunted growth when compared to its peers across the world. She observed that several countries rated along with Nigeria in the 1960s as third world countries have made tremendous progress in transforming from the third world position into a first world because of the efforts made to develop those countries. The former Nigerian Minister noted that Nigeria lost a staggering $\$ 600$ billion in the last five decades to corruption in governmental circles, as she puts it, ... "our country has earned more than \$600billion in the last five decades and yet can only boast of a United Nations Human Development Index score of 2 out of 1 proximate to that of Chad and maternal mortality rate similar to that of Afghanistan. Nothing reveals the depth of our failures than such performance indicators considering the vastly greater possibilities that we have been bestowed." She also observed that the country was rated number 32 on countries with high corruption index, adding that the rating was as a result of the systemic corruption in Nigeria which continues to fester.

In his inaugural lecture in 2010, Kunle Ajayi, a Professor of International Relations, noted that corruption could cost Nigeria the SC seat. He argued that the epidemiology of corruption in the country is such that no institution of state is immune from the corruption virus. With regard to a SC seat for Nigeria, he said that the country leaders would have to first of all address the image problem because "corruption is one of the factors affecting Nigeria's image abroad." Some Nigerian scholars' have also observed the corruption trend in Nigeria and concluded that the country's leaders are to blame for the rots and Nigeria's descent into infamy. James, C. and Agazie, James argued persuasively in their 2013 article on corruption in Nigeria thus:

If you judge African nations by the degree of corruption that goes on at both the governmental and local levels, Nigeria has no equal. To say that there is no corruption in Nigeria is to make an irresponsible statement, despite glaring evidence to the contrary. Pejoratives abound in every discussion about Nigeria which is considered to be the so - called "Epitome of African corruption."

The authors' sentiments are faultless going by the prevailing situation in that country. The burdensome truth is that Corruption walks naked in Nigeria and the political leadership in Nigeria itself is deeply enmeshed in that practice. There is recent evidence to support this claim. For instance, the incumbent Nigerian government led by President Jonathan has perhaps surpassed the ignoble corruption record which was inherited from the past Nigerian governments as proven treasury looters of Nigeria's commonwealth have been awarded national honours as "outstanding promoters of unity, patriotism and national development." The case of former Nigeria's military dictator and Head of State late General Sani Abacha 1993- 
1998 is offers a cursory example. The Nigeria government gave him a posthumous centenary award back in March 2014 during the celebration of 100 years of Nigeria's amalgamation as a single geographical entity by the British colonial authorities in 1914.

This was despite the fact that the award recipient in his life time stole a staggering \$6billion from Nigeria's coffers while in power. As NuhuRibadu, pioneer chairman of the Economic and Financial Crimes Commission (EFFC), said at an event in London in November 2006, "Abacha took over $\$ 6$ billion from Nigeria." At of that sum, $\$ 500 \mathrm{~m}$ was recovered under the presidency of Olusegun Obasanjo 1999-2007, finance minister OkonjoIweala said. This is inimical to the candidacy of a country seeking to represent Africa on the SC. Notably, it was during the military regime of General Abacha that Nigeria became a pariah state in the international community the status that was reminiscent of the fate suffered by the defunct apartheid regime of South Africa due to the wild human right violations and state sponsored assassinations of dissenting voices in Nigeria. Alas the incumbent Nigerian government thought it worthwhile to recognize that same individual with a posthumous award national award. This is symptomatic of a state's culpability in aiding and abetting corruption. Suffice to say that it was the inclusion of Abacha's name on the lists of awardees that forced Nigerian Nobel Laureate Prof Wole Soyinka to reject his own centenary award. Soyinka described Abacha as a "murderer and thief of no redeeming quality." In March 2014, barely a week after President Jonathan bestowed that posthumous award on the late Head of State, Gen. Sani Abacha, for his "contributions to the nation," the United States ordered a freeze on another $\$ 448 \mathrm{~m}$ in assets looted by the ex-dictator and his accomplices. According to Mythili Raman, the acting assistant attorney general in the department of justice, "General Abacha was one of the most notorious kleptocrats in memory, who embezzled billions from the people of Nigeria, while millions lived in poverty."

Again, this is an indictment of the Nigerian government. The US department described the forfeiture as "the largest civil forfeiture action to recover the proceeds of foreign official corruption ever brought by the department." Similarly, Transparency International (TI), an anti-corruption group, had in June 2014 criticized the decision of the Nigerian government to drop corruption charges against Mohammed Abacha, the son of the late Gen. Sani Abacha who was facing charges for assisting his late father to "steal and lauder" millions of dollars from government's coffers between 1995 and 1998.

The TI's regional director for Sub-saharan Africa, Chantal Uwimana, expressed the group's disapproval of the Nigeria's government decision in June 2014 thus: "allowing the theft of public funds to go unpunished sends the wrong message that those with powerful connections can act with impunity." His submission captures it all as corruption with impunity reigns supreme in the country particularly in governmental quarters where the virus is bred. A former United States Ambassador to Nigeria, John Campbell noted in a recent interview with Punch Nigerian Newspaper that corruption is deeply rooted in Nigeria He said: "I would pay more attention to corruption. It is mind-boggling how millions of dollars go missing." In the same vein, Campbell's compatriot Bissa Williams, the United States deputy assistant secretary, bureau of African affairs, gave her opinion about the corruption problem in Nigeria in an interview with the Vanguard Nigerian Newspaper, the American official said frankly: "if you ask me, I would say that corruption is extremely high in this country; there is no other way to say this."

Likewise, the United States government itself had in a "detailed and frank" assessment report on corruption in Nigeria published in 2013, entitled "Corruption and Lack of Transparency in Government" alleged that, in Nigeria, "Massive, widespread and pervasive corruption affected 
all levels of government and the security forces." The report alleged further that even judicial officials were not left out of the "massive corruption ring", the Nigerian government was heavily indicted of not implementing the law on corruption with the seriousness it deserve, thus encouraging and deliberately allowing "officials to frequently engage in corrupt practices with impunity." The foregoing indicates as earlier stated that the political leadership in Nigeria aids and abet corruption. Consequently, the question that begs for answer is: can Nigeria obtain the United States support for its UNSC ambition with the prevalence of state engineered corruption in that country?

This self-inflicted problem rubbishes Nigeria's credentials and claims for the UNSC seatSince the beginning of 2014, there have been allegations of corruption in government circles in Nigeria, the biggest of which was the allegation made by the immediate past governor of the central bank of Nigeria LamidoSanusiLamido that a colossal $\$ 20$ billion had gone missing from the federation account, for daring to expose the scandal, the CBN governor was asked to proceed immediately on terminal leave by the Nigerian government without verifying the authenticity of his allegations first. It later emerged that there were elements of truth in Sanusi's allegations as both the Nigerian National Petroleum Corporation and the incumbent Jonathan Presidency itself acknowledged on national and international television that "only $\$ 10.8$ billion was unaccounted for. .." However, the then CBN governor insisted that \$20 billion got missing and not $\$ 10.8$ billion the Nigerian government admitted was "unaccounted for." Now, this particular case is instructive with regard to corruption in Nigeria for two reasons: first, it vindicated the 2013 US corruption report on Nigeria cited above that the Nigerian government allows corruption to thrive. Second, it also give credence to the arguments made earlier that impunity thrives in Nigeria; otherwise, as at the time of writing this dissertation, none of the state's officials that heads the government ministries and corporation where the $\$ 10.8$ billion got missing or "unaccounted for" to use Nigerian government phrase has been relieved of their positions and handed over to the security agencies for prosecution which should be the case in a country where punishment is meted out on law offenders.

Unfortunately, the two female ministers under whose watch this financial atrocity was committed - Okonjo Iweala and Diezani Madueke still retain their governmental portfolios as the country's finance and petroleum ministers respectively despite massive calls for their sacking and prosecution from the Nigerian public. Again, it's instructive to note that the admittedly "unaccounted for" $\$ 10.8$ billion dollars in Nigeria is more than the combined Gross Domestic Product (GDP) of African countries such as Sierra Leone $\$ 4.929$ billion Cape verde $\$ 1.888$ billion and Swaziland $\$ 3.791$ billion which have a total GDP of $\$ 10.608$ billion going by the world bank GDP figures of countries in the world as at 2013.

This is the consequence of institutionalized corruption in Nigeria which the state itself has helped to fester in recent times as elucidated above. The implication of this therefore is that Nigeria has a burden of morality to contend with as the search for a UNSC permanent seat continues. As argued in this present chapter, corruption is responsible for all the vices in Nigeria including the security situation occasioned by the terror activities of Boko Haram - the Islamists fundamentalist group. As former United States' Secretary of State Hilary Clinton, said about Nigeria in a public interview with ABC's Robin Roberts, "they have squandered their oil wealth, they have allowed corruption to fester and now they are losing their territory because they wouldn't make hard choices." 
The above indicates that Nigeria has not been able to put its house in order as expected. The country's continued failure in this regard poses a huge challenge for its bid for the UNSC seat. The irony of the situation is that the same crop of leaders that presided over the rots in the system has been the most vociferous campaigners for Nigeria's bid. Second, Nigeria was a signatory to the African Union Convention on Preventing and Combating Corruption which was adopted on 11 July 2003 by the 2nd ordinary session of the Assembly of the Union in Maputo. The country was also a signatory to the UN Convention against Corruption which came into force on 14 December 2005. Nigeria has however repeatedly failed to uphold the principles of these conventions thus placing a moral question on the country's eligibility for the SC seat. How then can a country which has failed to act in accordance with these basic principles leverage on the same Organizations to secure a permanent seat for itself? This is simply paradoxical. Corruption potentially remains the greatest obstacle to Nigeria's ambition for the UNSC seat.

Bad Leadership - Bad leadership in Nigeria also constitutes a major impediment to the Nigerian dream of getting a SC seat. Bad governance has prevented a massively endowed country from attaining its potential in every aspect of human development. As far back as 1984, renowned novelist Chinua Achebe gave a damming view about the leadership crisis in Nigeria. Although, at the time he wrote that book the trouble with Nigeria, political leadership was not as bad as it is today. However that particular era set the stage for the current leadership rots being experience today in Nigeria. If not attended to urgently like a patient in an intensive care unit facility of a hospital, this could lead to Nigeria being officially declared as a failed state. Achebe explained Nigeria's leadership problem thus: "The trouble with Nigeria is simply and squarely a failure of leadership ... the Nigerian problem is the unwillingness or inability of its leaders to rise to the responsibility, to the challenge of personal example which are the hallmarks of true leadership." The most worrisome thing about this submission is that the leadership problem still plagues the country till today far worse than the case was then. This is a major problem for Nigeria ambition. The failure of leadership has brought the Nigerian state to where it is at present, as Achebe again noted: "Nigeria is what it is because its leaders are not what they should be." It will take a direct or indirect beneficiary of the Nigerian failed leadership system to fault this thought as it aptly captures the Nigerian leadership situation.

For Nigeria to be taken seriously by the international community as a contender for the SC seat, the leadership infrastructure has got to be redeemed. The current leadership situation does not in any way suggest sanity, as Friday Jarikre opined, "In a sane society, leadership is influence but in Nigeria leadership is affluence and how much a leader can amass from the collective patrimony of the people." This brings us back to the argument made earlier that corruption birthed all other malaises that Nigeria faces currently. Leadership failure will be a contributory factor to Nigeria not getting the SC seat if these issues are not addressed. As Wakdok Samuel said, "the story of Nigeria is a pathetic one. ... A country with rich human and natural resources has been brought to the brink due to years of bad leadership."

A Retired Nigerian Ambassador DapoFafowora, was of the view that the leadership problem in the Nigerian domestic scene had caused the country's leaders to be held in low esteem abroad over the years because of their serial failure to institutionalize probity and good governance in the country. The retired Nigerian diplomat said leadership and respect are won abroad by showcasing exemplary leadership at home and not just throwing money around as it has been the case with Nigeria. He stated: "Leadership and respect are not won by simply throwing money around, but by setting an example of good government and probity in Nigeria's public 
life. Nigeria's foreign policy would have had a major success and impact in Africa, but for the low esteem in which Nigerian leaders are generally held abroad. Implicitly, a failed domestic leadership cannot not produce a successful leadership abroad because it is said that charity begins at home.

Weak Democratic Institutions - Another one of the factors that could count against Nigeria's candidacy for the SC seat is its weak democratic institutions. The Nigerian democratic system has not yet recorded appreciable progress in the same way other emerging democracies in Africa havedone. While democracy is waxing stronger in countries such as Senegal, Ghana and South Africa, the contrary is the case in Nigeria as democratic institutions have been debased. Electioneering processes are monetized to the extent that those who get elected into public offices are often the highest bidders. As a result of this, Nigeria operates the most expensive and wasteful democracy in the world. Given these realities, the odds might be stacked against Nigeria's candidacy despite its credentials because of the premium placed on sound democratic institutions and good governance by Western countries such as United States, Britain which are both permanent members of the UNSC (Saliu and Omotola, 2008). The country's history of intermittent coups arguably the worst in Africa which produced seven military regimes in 33 years is due largely to the absence of strong democratic institutions.

Insecurity - The security situation in Nigeria currently is inimical to its UNSC ambition. This owes largely to the corruptness of the country's ruling class which has failed to bring the situation under control despite billions of dollars budgeted for security in the last few years. The most challenging of it all is the Boko Haram insurgency in the North Eastern part of Nigeria which has led to the death of many innocent people - including security personnel. This has had negative foreign policy implications for Nigeria in the sense that it portrays Nigeria to the outside world as a country slipping gradually into anarchy; as a country where leadership infrastructure is collapsing; as a country where the state has lost the monopoly of violence. Thus, wherever global terrorism is mentioned Nigeria will be cited as an example. This problem flows is as a result of the corruption pandemic which then leads us to the conclusion that Nigeria's domestic problems are interwoven. Against the background of the foregoing, the foreign policy machinery of the Nigerian state would have to pay urgent attention to these issues of religious terrorism.

Mass Poverty - The problems of corruption and bad leadership has had a corresponding effect on the generality of Nigerian masses over the years. Despite huge revenue from crude oil and gas exports, a preponderant number of Nigeria's population still remains chronically poor with a staggering $69 \%$ of the domestic populace living in acute poverty. According to the Nigerian Statistician General, and the Head of National Bureau of Statistics Yemi Kale, "In 2004, Nigeria's relative poverty measurement stood at $54.4 \%$ but increased to $69 \%$ or 112.518 million Nigerians in 2010." This is staggering when compared to the World Bank population total of Nigeria put at 173.6 million in 2013.

The question that arises from this is, can a country suffering from this self-inflicted social malady push successfully for a UNSC permanent seat? Mass poverty in the midst of abundance is due majorly to the corrupt practices in public offices and bad leadership in Nigeria. The case of Nigeria's Niger Delta region is particularly ironic in this regard; despite the fact that oil is produced there, the poverty level in the region is extremely high due to rampant corruption and heartless mismanagement of the oil proceeds by states' officials. As Joseph Ebegbulem, Dickson Ekpe and TheophilusAdejumo expressly noted, 
What is going on in the Niger Delta region is a clear demonstration of the fact that after many decades of oil exploration in the region, the natives have become poorer and less empowered, contrary to what one would have expected, judging from cases of oil countries like Saudi Arabia and Venezuela, who have learnt how to manage the excess wealth generated by oil. Crude oil as an essential commodity in this technological age; even though it has empowered many countries that possess it, has ended up impoverishing some countries like Nigeria, who cannot manage the enormous profit it generates as a result of corruption, selfishness and greed.

The importance of the above is instructive in the sense that it proves further that Nigeria's domestic scene is fraught with maladies which the country's leaders have foisted on it. A cursory look at that 112.5 million figure of people living in abject poverty despite huge revenue from oil and gas sales shows that the total number of Nigerians that are poverty stricken outstrips the total human population of seven countries West African countries namely, Ghana , Mali , Senegal , Burkina Faso , Cote d' Ivoire, Chad; and Liberia. These countries have a population total of 109. 704 million people which then leads to the conclusion that there are more people living in abject poverty Nigeria than the whole populations of these countries put together. Available data also suggests that there are more people living in poverty in Nigeria than the individual populations of South Africa - 52.98 million in 2013, Ethiopia 94.10 million 2013; and Egypt 82.06 million - also in 2013 according to the 2013 World Bank data on the countries mentioned. This is the accumulated results of corruption and bad leadership in Nigeria.

\section{RECOMMENDATION}

For Nigeria to clinch the UNSC permanent seat, it has to first and foremost get out of its selfimposed socio-political and economic maladies that plague the country. According to an African proverb, "one should first assess the cloth an individual is putting on before accepting the clothes he/she is offering as a gift." Implicitly, it defiles logic for a naked man to give out clothes as a generous gesture. This aptly describes the Nigerian situation in respect to its desire to represent Africa on an enlarged UNSC seat when socio-political and economic statistics on the ground suggest that the country is unworthy of taking up such a role today given the failure of leadership at home with its attendant effects in the proliferation of corrupt practices with impunity in the country. Therefore, it is as a result of this existential reality that this study employs the usage of the phrase "moral burden" to dissect Nigeria's paradoxical situation. In essence, the recommendation is that Nigeria must first put its house in order before aspiring to represent Africa in global politics.

Suffice to say that the claimants to Nigeria's right to the UNSC seat have forgotten the dictum that says, 'Charity begins at home'. Otherwise they should have known that the prevailing events on the domestic fronts will shape the trajectory of debates on matters of this nature. Nigeria as it is today has a moral burden on its neck with regard to making a successful push for the permanent membership seat on the SC of the UN. The moral burden represents the domestic condition which has been discussed in the foregoing. This study has identified five major domestic problems that will affect Nigeria's chances in getting a permanent UN seat on the SC. These are: the corruption pandemic, bad political leadership, weak democratic institutions, insecurity; and mass poverty amidst oil wealth. The following recommendations are offered in light of these domestic ills. First, Nigerian leaders and government should use the domestic scene as a springboard to showcase their seriousness about the country's candidacy for the UNSC seat by tackling corruption headlong. 
No country whose name is quickly linked to corruption in discourses can ever be allowed to ascend to an exalted position like the permanent membership of the UNSC. Consequently, the architects of Nigeria's bid for a UNSC seat must stop being delusional that the country deserves the seat on the basis of its historical strength as statistics have shown that Nigeria is extremely incapable to occupy that seat unless practical and results-oriented steps are taken to address the ugly situations on the domestic scene by the country's political leadership.

\section{CONCLUSION}

Thus far the paper has been able to draw a link between Nigeria's past roles in African decolonization issues and its present political activities regarding the UNSC permanent seat ambition. It reckons that although Nigeria has impressive credentials needed to lay claim to that seat, however, as things stand, it will be extremely difficult if not impossible for Nigeria to realize this dream if the issues discussed in this paper are not addressed urgently with demonstrable and convincing results. The Nigerian case for the UNSC permanent seat is paradoxical in the sense that the country wants to represent Africa in the apex decision making organ in the international system - the UNSC when it has failed unremittingly to show leadership at home and also failed to fulfil its international obligations with regard to upholding the AU and UN conventions on corruption which it is a signatory to.

How then can the country leverage on these diplomatic platforms to secure the UNSC seat because Nigeria would have to secure the nod of AU and UN member states and then the UNSC P5 members to get that seat? This places Nigeria in a dicey situation.

\section{Notes}

1. The Search For A UN Security Council Permanent Seat - A Case For Nigeria," Text of a Speech by His Excellency, Dr.Abdullahi Adamu, Executive Governor of Nasarawa State, Nigeria at the Public Presentation of a Book on President Olusegun Obasanjo at Accra - Ghana, Saturday, August 13, 2005, p. 4.

2. Aluko O. (1976) Ghana and Nigeria, 1957-1970, A Study In Inter-African Discord, Rex Collings Ltd, London, p. 74.

3. Garba J. N. (1987) Diplomatic Soldering, The Conduct Of Nigerian Foreign Policy, 1975-1979, Spectrum Books Ltd, Ibadan, Nigeria, p. 101.

4. Nigeria - South Africa Baseline Study, Brief No 44, September 2013, Open Society Foundation For Africa, South African Foreign Policy Initiative, (SAFPI), p. 11.

5. Sani S. (2012), Nigeria's Foreign Policy, Globalization and National Security, in Review of Nigeria's Foreign Policy: Issues and Perspectives, E. Anyaoku (ed), Nigerian Institute of International Affairs, Lagos, Nigeria.

6. Osuntokun A. (2005) "Nigeria and the United Nations: Service Deserves Its Rewards," in Nigeria and the United Nations Security Council, B. A. Akinterinwaed, Vantage Publishers, Ibadan, Nigeria, p.239.

7. Akinterinwa B. A. (2005) Nigeria and the Permanent Membership of the United Nations Security Council: Dynamics and Definienda, in Nigeria and the United Nations Security Council, B.A. Akinterinwaed, Vantage Publishers, Ibadan, Nigeria, pp. 71-72.

8. The UN Universal Declaration of Human Rights, available online at: www.ohchr.org/en/udhr/document/udhr/translations/eng.pdf.

9. Sani S. (2012), Nigeria's Foreign Policy, Globalization and National Security, in Review of Nigeria's Foreign Policy: Issues and Perspectives, E. Anyaoku (ed), Nigerian Institute of International Affairs, Lagos, Nigeria, pp. 70-71.

10. Mr Prime Minister, A Selection of Speeches Made by Alhaji (Sir) Abubakar Tafawa Balewa, Prime Minister of the Federal Republic of Nigeria, 1960-1966, Nigerian National Press Ltd, Apapa, Lagos, Nigeria, 1964, p. 51. 
11. The Nigerian Guardian Newspaper, September 22, 1997.

12. The Punch Newspaper, June 27, 2014.

13. The Punch Newspaper, March 6, 2014

14. The Punch Newspaper, June, 2014

15. Ajayi K. (2010), Seeking Equality in An Unequal World: Nigeria and the Permanent Security Council Seat Aspiration, University of Ado-Ekiti, Nigeria, 22nd Inaugural Lecture,

16. James C. and Agazie, J (2013), Nigeria Has the Most Outrageous Corruption - Leaders To Blame, available online at: nigeriamasterweb.com/blog/index.php/2013/09/08.

17. Nigeria's the Punch Nigerian Newspaper, July 3, 2014, available online at: www.punchng.com.

18. The Nigerian Guardian Newspaper, September 22, 1997.

19. The Punch Newspaper, June 27, 2014.

20. The Punch Newspaper, March 6, 2014

21. The Punch Newspaper, June, 2014

22. The Punch Newspaper, August 3, 2014

23. The Vanguard Newspaper, April 6, 2014

24. The Punch Newspaper Editorial on "Damming US Corruption Report On Nigeria" March 19, 2014, available online at: www.punchng.com

25. www.worldbank.org/en/country/sierraleone.

26. www.worldbank.org/en/country/CapeVerde.

27. www.worldbank.org/en/country/swaziland.

28. As the World Rallies For Nigeria, available online at: www.thisdaylive.com/articles/as-the-world-ralliesfor-nigeria.

29. The African Union Convention on Preventing and Combating Corruption, available online at: www.au.int/.../AFRICAN Union-CONVENTION-PREVENTING_C....

30. The UN Convention against Corruption, adopted by the General Assembly of the United Nations on 31 October 2003 at the UN Headquarters in New York, Nigeria became a signatory to the convention on 9, December 2003 two months after it adoption. Available Online at: https://www.unodc.org/unodc/en/treaties/CAC. 31

31. Achebe C. (1984) The trouble with Nigeria, Heinemann Publishers, p. 1.

32. Jarikre F. (2012) "Nigeria and its Fading Dreams", Urhobo Times, www.urhobotimes.com/individual, p. 1.

33. Wkdok, S. S. How African Underdeveloped Africa. available online at: www.credoworld.blogspot.com.

34. Fafowora. O. (1984), The Role of the Ministry of Foreign Affairs in the Formulation of Nigerian Foreign Policy: Personal Reminiscences. The Quarterly Journal of Administration, Vol. xvii, Nos. 3 \& 4, April/July, pp. 92-110.

35. Wkdok. S. S. How African Underdeveloped Africa." available online at: www.credoworld.blogspot.com.

36. Adebajo. A. (2008), Hegemony on a Shoestring, Nigeria's Post-Cold War Foreign Policy," in Gulliver Troubles, Nigeria's Foreign Policy after the Cold War, A. Adebajo and A. R. Mustapha (eds.) University of KwaZuluNatal Press, Scottsville, South Africa, p. 1.

37. Azazi. O.A (2012), Internal Security and Nigerian Foreign Policy, in Review of Nigeria's Foreign Policy: Issues and Perspectives, E. Anyaoku ed, Nigerian Institute of International Affairs, Lagos, Nigeria

38. 112.5 Million Nigerians Live in Poverty - NBS, Punch Nigerian Newspaper, February 12, 2012, available online at: www.punchng.com.

39. World Bank Data On Nigeria, available online at: data.worldbank.org/country/Nigeria.

40. Ebegbulem. J.C. et al (2013), Oil Exploration and Poverty in the Niger Delta Region of Nigeria: A Critical Analysis, International Journal of Business and Social Science, Vol. 4. No. 3, March 2013. 
41. www.worldbank.org/en/country/Ghana.

42. www.worldbank.org/en/country/Mali.

43. www.worldbank.org/en/country/Senegal.

44. www.worldbank.org/en/country/BurkinaFaso .

45. ewww.worldbank.org/en/country/Coted'Ivoir.

46. www.worldbank.org/en/country/Chad.

47. www.worldbank.or/en/country/Liberia 